\title{
UJI PENDAHULUAN TOKSISITAS AKUT DERMAL SEDIAAN SALEP EKSTRAK ETANOL 70\% DAUN BINAHONG (ANREDERA SCANDENS (L.) MOQ.) TERSTANDAR
}

\author{
P. O. Samirana*, D. M. N. Pratiwi, N.W. Musdwiyuni, D. A. A. Andhini, A. N. Mahendra, A. \\ A. G. R. Yadnya-Putra
}

Progam Studi Farmasi Fakultas Matematika dan Ilmu Pengetahuan Alam Universitas Udayana *Email: oka_samirana@unud.ac.id

\begin{abstract}
ABSTRAK
Daun binahong (Anredera scandens (L.) Moq.) telah banyak diteliti aktivitas farmakologisnya dan sudah dilakukan standarisasi oleh Farmakope Herbal Indonesia, sehingga mudah dikembangkan menjadi obat herbal terstandar. Ekstrak etanol 70\% daun A. scandens (L.) Moq.berpotensi sebagai sediaan dalam menyembuhkan luka terutama luka eksisi. Uji pendahuluan toksisitas akut dermal bertujuan untuk mengetahui ada atau tidaknya kematian hewan uji setelah diberikan sediaan salep ekstrak etanol 70\% daun A. scandens (L.)Moq.secara topikal agar memenuhi persyaratan menjadi obat herbal terstandar.Penelitian secara eksperimental ini digunakan tikus putih betina galur Wistar sebanyak 8 ekor yang terdiri dari 1 ekor tikus telah di aklimatisasi selama 1 minggu.Objek uji dibagi dalam kelompok kontrol normal, uji basis salep, dan tujuh kelompok perlakuan (diberikan olesan basis salep ekstrak etanol 70\% daun A. scandens (L.) Moq.dosis $1000 \mathrm{mg} / \mathrm{KgBB}, 2000$ $\mathrm{mg} / \mathrm{KgBB}$, dan $5000 \mathrm{mg} / \mathrm{KgBB}$ ). Hasil pengamatan menunjukkan bahwa pemberian sediaan salep ekstrak etanol $70 \%$ daun A.scandens (L.) Moq.tidakmenyebabkan adanya tikus yang mati dengan pengamatan selama 14 hari, sehingga ekstrak etanol 70\% daun A.scandens (L.) Moq.telah memenuhi standar menurut Farmakope Herbal Indonesia dilihat dari parameter rendemen ekstrak, kadar air ekstrak, kadar abu total, kadar abu tidak larut asam, dan kadar flavonoid total.
\end{abstract}

Kata kunci: Anredera scandens, sediaan salep, luka eksisi, toksisitas akut dermal

\begin{abstract}
Binahong leaves (Anredera scandens (L.)Moq.) has been widely studied for its pharmacological activity and has been standardized by Pharmacopoeia Herbal Indonesia, so that it can be developed easily into a standardized herbal medicine. A $70 \%$ ethanol extract of A.scandens (L.) Moq. leaves was potential as a preparation in healing wounds, especially excision wounds. The preliminary test of acute dermal toxicity aimed to determine whether there was death or not in the test animals after administration of a $70 \%$ ethanol extract of A.scandens (L.) Moq. leaves topically so that it meets the requirements of being a standardized herbal medicine. This experimental research used 8 Wistar female rats during which 1 rat had been acclimatized for 1 week. The test object was divided into the normal control group, the ointment-based test, and the seven treatment groups (given an ointment base of $70 \%$ ethanol extract of A.scandens (L.) Moq leaves at a dose of $1000 \mathrm{mg} / \mathrm{KgBW}$, $2000 \mathrm{mg} / \mathrm{KgBW}$, and $5000 \mathrm{mg} / \mathrm{KgBW}$ ). The results showed that the application of the preparation of $70 \%$ ethanol extract of A.scandens (L.) leaves Moq. did not cause a deadth of rat within observation for 14 days, therefore the $70 \%$ ethanol extract of A.scandens (L.) Moq. leaves has met the standard according to the Indonesian Herbal Pharmacopoeia seen from the parameters of yield of extract, water content of extract, total ash content, acid soluble ash content, and the total flavonoid content.
\end{abstract}

Keywords: acute dermal toxicity, Anredera scandens, excision wounds, ointment preparations

\section{PENDAHULUAN}

Indonesia memiliki berbagai tanaman yang berpotensi dijadikan sebagai tanaman obat seperti tanaman binahong. Daun binahong (Anredera scandens (L.) Moq.) telah banyak diteliti aktivitas farmakologisnya dan sudah dilakukan standarisasi oleh Farmakope Herbal Indonesia, sehingga mudah dikembangkan menjadi obat herbal terstandar (Kementrian Kesehatan RI, 2011). Daun binahong
(Anredera scandens (L.) Moq.) telah terbukti memiliki aktivitas antibakteri, antiinflamasi, dan antitukak lambung (Fitria, 2009; Wardhani dan Sulistyani, 2012; Feybriyanti, 2011; Samirana et al., 2014). Selain aktivitas farmakologis diatas, ekstrak etanol $70 \%$ daun A. Scandens (L.) Moq. dapat digunakan untuk menyembuhkan luka yaitu luka eksisi dan luka bakar (Karismawan, 2013; Samirana dkk., 2016). Ekstrak etanol $70 \%$ daun A. scandens (L.) Moq. dalam menyembuhkan luka eksisi 
diperkuat dengan penelitian mengenai mekanisme penyembuhan luka eksisi seperti, angiogenesis, epitelisesi, dan fibrogenesis (Ariadi, 2016, Subratha, 2016 dan Ardinata, 2017).

Ekstrak etanol $70 \%$ daun A. scandens (L.) Moq. berpotensi dapat dijadikan sebagai sediaan dalam menyembuhkan luka terutama luka eksisi. Berdasarkan penelitian Ariadi (2016), Subratha (2016), dan Ardinata (2017), menyebutkan bahwa basis salep yang digunakan sebagai bahan pembawa ekstrak etanol $70 \%$ daun A. scandens (L.) Moq. yaitu basis hidrokarbon atau lemak yang baik digunakan untuk penyembuhan luka eksisi. Basis hidrokarbon yang digunakan terdiri dari adeps lanae $15 \%$ dan vaselin album $85 \%$.

Untuk membuat suatu bahan baku dan bahan pembawa obat tradisional yang dalam hal ini yaitu ekstrak etanol $70 \%$ daun $A$. scandens (L.) Moq. yang akan dijadikan sebagai obat herbal terstandar maka perlu dilakukan uji praklinik. Uji praklinik terdiri dari uji farmakologis dan uji toksisitas dengan menggunakan hewan uji (Hernani dkk., 2009 dan Remirez, 2006). Sediaan salep ekstrak etanol $70 \%$ daun A. scandens (L.) Moq. telah terbukti memiliki aktivitas farmakologis sebagai penyembuhan luka eksisi, namun untuk mengetahui keamanaan sediaan tersebut maka perlu dilakukan uji toksisitas.

Ekstrak etanol $70 \%$ daun A. scandens (L.) Moq. yang akan diaplikasikan secara topikal dengan pembawa salep agar memenuhi persyaratan menjadi obat herbal terstandar maka perlu dilakukan uji toksisitas dermal. Uji toksisitas dermal penting untuk dilakukan karena kulit merupakan bagian dari tubuh yang rentan untuk dimasukkan zat berbahaya yang akan masuk ke dalam sistem sistemik (Chandra et al., 2015; Noakes and Sanderson, 1969). Untuk skrining awal mengetahui toksisitas suatu bahan terhadap kulit untuk pertama kali, maka perlu dilakukan uji toksisitas akut dermal. Sehingga pada sediaan salep ekstrak etanol $70 \%$ daun A. scandens (L.) Moq. perlu dilakukan uji toksisitas akut dermal untuk melihat respon awal bentuk sediaan ini terhadap respon kulit (Moore et al., 2013; OECD, 1987).

Dari penjelasan diatas, sehingga perlu dilakukan uji pendahuluan toksisitas akut dermal sediaan salep ekstrak etanol $70 \%$ daun A. scandens (L.) Moq. Uji pendahuluan toksisitas akut dermal bertujuan untuk mengetahui ada atau tidaknya kematian pada hewan uji setelah diberikan sediaan salep ekstrak etanol $70 \%$ daun A. scandens (L.) Moq., sehingga dapat digunakan untuk menentukan dosis awal yang akan digunakan untuk uji toksisitas akut dermal sediaan salep ekstrak etanol $70 \%$ daun A. scandens (L.) Moq. Pada uji ini digunakan dosis 1000 $\mathrm{mg} / \mathrm{Kg} \mathrm{BB}, 2000 \mathrm{mg} / \mathrm{Kg} \mathrm{BB}$, dan $5000 \mathrm{mg} / \mathrm{Kg}$ $\mathrm{BB}$ dikarenakan belum terdapat adanya data mengenai struktur kimia dari ekstrak etanol $70 \%$ daun A. scandens (L.) Moq. (BPOM, 2014).

Penelitian ini bertujuan untuk mengetahui dosis $1000 \mathrm{mg} / \mathrm{Kg}$ BB, 2000 $\mathrm{mg} / \mathrm{Kg} \mathrm{BB}$, dan $5000 \mathrm{mg} / \mathrm{Kg}$ BB dapat menimbulkan kematian pada tikus putih betina galur Wistar setelah pemberian sediaan salep ekstrak etanol $70 \%$ daun A. scandens (L.) Moq. secara akut dermal.

\section{MATERI DAN METODE}

\section{Bahan}

Bahan-bahan yang akan digunakan yaitu etanol 70\% (Bratachem $\left.{ }^{\circledR}\right)$, etanol 96\% (Bratachem $\left.{ }^{\circledR}\right), \quad \mathrm{HCl} \quad 37 \% \quad\left(\right.$ Merck $\left.^{\circledR}\right)$, rutin( Merck $\left.^{\circledR}\right)$, aluminium klorida $\left(\right.$ Merck $\left.^{\circledR}\right)$, dan natrium asetat $\left(\right.$ Merck $\left.^{\circledR}\right)$ yang masing masing berderajat pro analisis, kertas saring bebas abu, akuades, dan $\mathrm{NaCl} 0,9 \%$ (PT. Widatra Bhakti) yang masing - masing berderajat teknis.

\section{Peralatan}

Alat yang digunakan adalah toples kaca, mortir, stamper, sudip, cawan porselen, pot salep, sendok tanduk, timbangan analitik $\left(\mathrm{AND}^{\circledR}\right)$, rotary evaporator $\left(\right.$ Eyela $\left.^{\circledR}\right)$, oven, alat-alat gelas, kertas saring, perban elastis, plester, pencukur rambut, jangka sorong, penggaris, spektrofotometer UV-Vis Genesys $^{\circledR}$, sentrifugator, krus porselin, dan tanur.

\section{CARA KERJA}

Determinasi Tanaman

Determinasi tanaman dilakukan oleh CV. Merapi Farma Herbal. Proses determinasi dilakukan oleh lembaga yang bersangkutan 
dan selanjutnya hasil determinasi akan diberitahukan kepada peneliti.

\section{Preparasi Ekstrak Etanol $\mathbf{7 0 \%}$ Daun Anredera scandens (L.) Moq.}

Serbuk daun A. scandens (L.) Moq.yang sudah kering ditimbang sebanyak $100 \mathrm{~g}$. Serbuk yang telah ditimbang dimaserasi dengan pelarut etanol $70 \%$ sebanyak $1 \mathrm{~L}$ selama \pm 24 jam dengan dilakukan pengadukan sesekali. Residu dimaserasi kembali dengan cara yang sama dengan pengulangan 2 kali. Maserat ditampung menjadi satu dan diuapkan dengan menggunakan alat Rotary evaporator pada suhu $50^{\circ} \mathrm{C}$, sehingga diperoleh ekstrak kental.

\section{Standarisasi Ekstrak Etanol 70\% Daun Anredera scandens (L.) Moq.}

1. Penetapan kadar air dari ekstrak etanol 70\% daun A. scandens (L.) Moq. dengan cara menimbang 1 gram ekstrak ke dalam botol timbang yang sebelumnya sudah ditara, selanjutnya dipanaskan dengan suhu $105^{\circ} \mathrm{C}$ selama 30 menit dan didinginkan dalam desikator, kemudian ditara kembali. Langkah ini diulang sebanyak 2 kali, kemudian ditentukan kadar airnya (Depkes RI, 1995).

2. Penetapan kadar abu total dilakukan dengan cara menimbang sebanyak 3 gram ekstrak etanol $70 \%$ daun $A$. scandens (L.) Moq. Sampel dimasukkan ke dalam krus porselin yang terlebih dahulu dilakukan pemijaran dan penaraan. Selanjutnya, sampel ekstrak dipijarkan hingga menjadi abu dan ditimbang hingga bobot konstan.

3. Penetapan kadar abu tidak larut asam dilakukan dengan cara abu hasil penetapan kadau abu total didihkan dengan $25 \mathrm{~mL}$ asam klorida encer selama 5 menit. Larutan disaring melalui kertas saring bebas abu dan dicuci dengan air panas, bagian yang tidak larut asam dikumpulkan. Hasil yang diperoleh kemudian dipijarkan dalam krus porselin hingga berat tetap.

4. Penetapan kadar flavonoid total dilakukan dengan menimbang 1 gram ekstrak etanol $70 \%$ A. scandens (L.) Moq., kemudian dilarutkan dengan 10
$\mathrm{mL}$ etanol $80 \%$ dan dilakukan sentrifugasi $1000 \mathrm{x}$ gravitasi selama 10 menit. Pembuatan larutan rutin sebanyak $10 \mathrm{mg}$ rutin yang dilarutkan dengan etanol $80 \%$. Larutan sampel ekstrak sebanyak $0,5 \mathrm{~mL}$ larutan uji ekstrak etanol $70 \%$ daun A. scandens (L.) Moq. dan larutan rutin dipipet secara terpisah, kemudian ditambahkan dengan $1,5 \mathrm{~mL}$ etanol $\mathrm{P}$, $0,1 \mathrm{~mL}$ aluminium klorida $\mathrm{P} 10 \%, 0,1$ $\mathrm{mL}$ natrium asetat $1 \mathrm{M}$, dan $2,8 \mathrm{~mL}$ akuades, kemudian diukur serapan pada panjang gelombang $425 \mathrm{~nm}$.

\section{Uji Pendahuluan Toksisitas Akut Dermal}

Salep dibuat dengan adeps lanae dan vaselin album dipanaskan dalam dalam wadah yang terpisah diatas waterbath pada suhu $40^{\circ} \mathrm{C}$. Setelah campuran tersebut diaduk dengan kecepatan konstan hingga homogen terbentuklah basis salep (Subratha, 2016; Puri, 2017). Untuk uji pendahuluan toksisitas akut dermal menggunakan konsentrasi ekstrak etanol $70 \%$ daun A. scandens (L.) Moq. sebesar $16 \%$, 32\%, dan $80 \%$.

Pengujian pendahuluan toksisitas akut dermal menggunakan hewan tikus betina galur wistar. Hewan tikus yang digunakan sebanyak 8 ekor dengan masing-masing kelompok terdiri dari 1 ekor tikus yang telah di aklimatisasi sebelumnya selama 1 minggu. Sesaat sebelum pengujian, bulu hewan dicukur dengan luas area $4 \mathrm{~cm} \times 4 \mathrm{~cm}$ dari permukaan tubuh tikus sebagai tempat pemaparan sediaan uji. Waktu pencukuran dilakukan kira-kira 24 jam sebelum diberikan sediaan uji. Pada bagian tengah kulit yang dicukur diberi tanda kotak sebagai area pemaparan sediaan uji dengan luas $3 \mathrm{~cm} \times 3 \mathrm{~cm}$.

Basis salep ekstrak etanol $70 \%$ daun $A$. scandens (L.) Moq., salep ekstrak etanol 70\% daun A. scandens (L.) Moq. dosis $1000 \mathrm{mg} / \mathrm{Kg}$ $\mathrm{BB}$, salep ekstrak etanol $70 \%$ daun $A$. scandens (L.) Moq. dosis $2000 \mathrm{mg} / \mathrm{Kg} \mathrm{BB}$, salep ekstrak etanol $70 \%$ daun A. scandens (L.) Moq. dosis $5000 \mathrm{mg} / \mathrm{Kg} \mathrm{BB}$ masingmasing dioleskan sebanyak $1,25 \mathrm{~g}$, ekstrak etanol 70\% daun A. scandens (L.) Moq. dosis $1000 \mathrm{mg} / \mathrm{Kg}$ BB dioleskan sebanyak 0,2 g, ekstrak etanol $70 \%$ daun A. scandens (L.) Moq. dosis $2000 \mathrm{mg} / \mathrm{Kg}$ BB dioleskan sebanyak $0,4 \mathrm{~g}$, dan ekstrak etanol $70 \%$ daun A. scandens (L.) Moq. dosis $5000 \mathrm{mg} / \mathrm{Kg} \mathrm{BB}$ 
dioleskan sebanyak $1 \mathrm{~g}$ pada bagian kulit tikus yang sudah dicukur dalam sekali pemberian selama 24 jam. Area pemaparan bahan uji ditutup dengan kasa steril dan dibalut dengan perban elastis serta plester yang tidak mengiritasi selama 24 jam.

Tabel 1. Perlakuan Masing-masing Kelompok Hewan Uji Pendahuluan Toksisitas Akut Dermal

\begin{tabular}{|c|c|c|}
\hline Kelompok & Perlakuan & Keterangan \\
\hline $\begin{array}{l}\text { Kontrol } \\
\text { Normal } \\
(\mathrm{K} 0)\end{array}$ & $\begin{array}{l}\text { Tidak diberikan } \\
\text { perlakuan }\end{array}$ & $\begin{array}{l}\text { Dikorbankan } \\
\text { pada hari ke-14 }\end{array}$ \\
\hline $\begin{array}{l}\text { Uji Basis } \\
\text { Salep (K1) }\end{array}$ & $\begin{array}{l}\text { Diberikan olesan basis } \\
\text { salep ekstrak etanol 70\% } \\
\text { daun A. scandens (L.) } \\
\text { Moq. }\end{array}$ & $\begin{array}{l}\text { Diberikan pada } \\
\text { hari ke-1 dan } \\
\text { dikorbankan pada } \\
\text { hari ke-14 }\end{array}$ \\
\hline $\begin{array}{l}\text { Perlakuan } \\
1(\mathrm{~K} 2)\end{array}$ & $\begin{array}{l}\text { Diberikan olesan ekstrak } \\
\text { etanol } 70 \% \text { daun } A \text {. } \\
\text { scandens (L.) Moq. dosis } \\
1000 \mathrm{mg} / \mathrm{Kg} \mathrm{BB}\end{array}$ & $\begin{array}{l}\text { Diberikan pada } \\
\text { hari ke-1 dan } \\
\text { dikorbankan pada } \\
\text { hari ke-14 }\end{array}$ \\
\hline $\begin{array}{l}\text { Perlakuan } \\
2 \text { (K3) }\end{array}$ & $\begin{array}{l}\text { Diberikan olesan ekstrak } \\
\text { etanol } 70 \% \text { daun } A \text {. } \\
\text { scandens (L.) Moq. dosis } \\
2000 \mathrm{mg} / \mathrm{Kg} \mathrm{BB}\end{array}$ & $\begin{array}{l}\text { Diberikan pada } \\
\text { hari ke-1 dan } \\
\text { dikorbankan pada } \\
\text { hari ke-14 }\end{array}$ \\
\hline $\begin{array}{l}\text { Perlakuan } \\
3 \text { (K4) }\end{array}$ & $\begin{array}{l}\text { Diberikan olesan ekstrak } \\
\text { etanol } 70 \% \text { daun } A \text {. } \\
\text { scandens (L.) Moq. dosis } \\
5000 \mathrm{mg} / \mathrm{Kg} \mathrm{BB}\end{array}$ & $\begin{array}{l}\text { Diberikan pada } \\
\text { hari ke-1 dan } \\
\text { dikorbankan pada } \\
\text { hari ke-14 }\end{array}$ \\
\hline $\begin{array}{l}\text { Perlakuan } \\
4 \text { (K5) }\end{array}$ & $\begin{array}{l}\text { Diberikan olesan salep } \\
\text { ekstrak etanol 70\% daun } \\
\text { A. scandens (L.) Moq. } \\
\text { dosis } 1000 \mathrm{mg} / \mathrm{Kg} \mathrm{BB}\end{array}$ & $\begin{array}{l}\text { Diberikan pada } \\
\text { hari ke-1 dan } \\
\text { dikorbankan pada } \\
\text { hari ke-14 }\end{array}$ \\
\hline $\begin{array}{l}\text { Perlakuan } \\
5 \text { (K6) }\end{array}$ & $\begin{array}{l}\text { Diberikan olesan salep } \\
\text { ekstrak etanol } 70 \% \text { daun } \\
\text { A. scandens (L.) Moq. } \\
\text { dosis } 2000 \mathrm{mg} / \mathrm{Kg} \mathrm{BB}\end{array}$ & $\begin{array}{l}\text { Diberikan pada } \\
\text { hari ke-1 dan } \\
\text { dikorbankan pada } \\
\text { hari ke-14 }\end{array}$ \\
\hline $\begin{array}{l}\text { Perlakuan } \\
6(\text { K7) }\end{array}$ & $\begin{array}{l}\text { Diberikan olesan salep } \\
\text { ekstrak etanol } 70 \% \text { daun } \\
\text { A. scandens (L.) Moq. } \\
\text { dosis } 5000 \mathrm{mg} / \mathrm{Kg} \mathrm{BB}\end{array}$ & $\begin{array}{l}\text { Diberikan pada } \\
\text { hari ke-1 dan } \\
\text { dikorbankan pada } \\
\text { hari ke-14 }\end{array}$ \\
\hline
\end{tabular}

Penutupan di area pemaparan bahan uji dilakukan untuk menjaga bahan uji tetap menempel pada kulit. Setelah 24 jam, sisa bahan uji yang masih menempel pada kulit tikus dihilangkan dengan $\mathrm{NaCl}$ 0,9\% (BPOM, 2014).
Pada pengujian pendahuluan toksisitas akut dermal yang diamati yaitu hewan uji yang mati selama pengujian. Pengamatan dilakukan selama 14 hari setelah pemberian sediaan uji. Apabila terdapat hewan uji yang mati selama pengujian, sebaiknya dilakukan uji konfirmasi kembali dengan penambahan 1 ekor tikus. Setelah 14 hari tikus dikorbankan sesuai dengan prosedur pemusnahan hewan (BPOM, 2014).

\section{HASIL DAN PEMBAHASAN}

\section{Determinasi Tanaman}

Daun binahong (Anredera scandens (L.) Moq.) yang digunakan diambil dari daerah Hargobinangun, Kecamatan Pakem, Kabupaten Sleman, Daerah Istimewa Yogyakarta, Sampel yang digunakan telah dilakukan determinasi sebelumnya dari CV. Merapi Farma Herbal. Sampel daun binahong (Anredera scandens (L.) Moq.) yang digunakan diambil dari satu tempat untuk meminimalisasi adanya kemungkinan variasi dari kandungan kimia tanaman yang dipengaruhi oleh iklim dan lingkungan. Berdasarkan data hasil determinasi yang menyatakan bahwa benar daun binahong (Anredera scandens (L.) Moq. yang digunakan dalam penelitian.

\section{Preparasi Ekstrak Etanol $\mathbf{7 0 \%}$ Daun $A$. scandens (L.) Moq.)}

Persyaratan rendemen dari ekstrak etanol $70 \%$ daun binahong (Anredera scandens (L.) Moq.) adalah tidak kurang dari $11,91 \%$ (Kemenkes RI, 2011), sehingga rendemen dari ekstrak etanol $70 \%$ daun $A$. scandens (L.) Moq.ini sudah memenuhi persyaratan yang telah ditetapkan yaitu rendemen ekstrak etanol $70 \%$ daun $A$. scandens (L.) Moq. yang diperoleh sebesar $20,55 \%$. Nilai rendemen ekstrak dalam proses ekstraksi dapat digunakan sebagai acuan jumlah ekstrak yang diperoleh dari suatu sampel. Hal ini juga terkait atas jumlah kandungan kimia yang terkandung dalam ekstrak, semakin besar rendemen ekstrak maka semakin banyak pula kandungan kimia yang terdapat pada sampel tersebut. 


\section{Standarisasi Ekstrak Etanol $70 \%$ Daun $A$. scandens (L.) Moq.}

Penetapan kadar air ekstrak etanol $70 \%$ daun A. scandens (L.) Moq.ini menggunakan metode gravimetri. Tujuan dari penetapan kadar air ekstrakuntuk memberikan batasan minimal kandungan air di dalam suatu bahan. Selain itu, penetapan kadar air bertujuan untuk melakukan standarisasi terhadap air dalam ekstrak sesuai dengan yang ditetapkan Farmakope Herbal Indonesia. Jika didapat hasil kadar air yang rendah menunjukkan stabilitas yang lebih baik dan kemungkinan degradasi kandungan bioaktif lebih kecil (Kunle, et al., 2012). Hasil penetapan kadar air ekstrak etanol $70 \%$ daun A. scandens (L.) Moq.yang didapat sebesar 4,84 $\pm 1,4 \%$. Berdasarkan hasil tersebut sudah memenuhi persyaratan untuk kadar air ekstrak etanol $70 \%$ daun A. scandens (L.) Moq.yaitu tidak lebih dari 8,85\% (Kemenkes RI, 2011).

Penetapan kadar abu ekstrak bertujuan untuk mengetahui baik atau tidaknya pengolahan bahan baku atau simplisia yang dikerjakan. Kadar abu total menunjukaan seberapa besar jumlah material yang tersisa setelah pembakaran baik itu senyawa anorganik, dapat termasuk abu non fisiologis yang berasal dari tanah dan pasir yang berada pada permukaan tanaman maupun abu fisiologis yang berasal dari jaringan tanaman itu sendiri (WHO, 1998; Kunle et al., 2012). Batasan minimal besarnya kandungan abu yang baik didalam ekstrak daun binahong dalam Farmakope Herbal Indonesia adalah tidak lebih dari 1,64\%. Hasil penetapan kadar abu ekstrak etanol $70 \%$ daun A. scandens (L.) Moq.adalah 1,47 $\pm 0,03 \%$. Hasil kadar abu total dalam ekstrak yang diperoleh masih dapat diterima karena masih berada pada rentang yang ditetapkan Farmakope Herbal Indonesia.

Penetapan kadar abu tidak larut asam ekstrak bertujuan untuk mengetahui pengolahan bahan atau dalam hal ini adalah ekstraksi dari simplisia yang dikerjakan baik dikerjakan atau tidak. Abu yang tidak larut asam tersusun sebagian besar dari silika dimana merupakan kontaminasi tanah (Kunle, et. al, 2012). Batasan minimal besarnya kandungan abu tidak larut asam yang baik didalam ekstrak daun binahong yang terdapat dalam Farmakope Herbal Indonesia adalah tidak lebih dari 1,64\%. Hasil penetapan kadar abu tidak larut asam ekstrak etanol $70 \%$ daun 184
A. scandens (L.) Moq. yang diperoleh sebesar $1,122 \pm 0,22 \%$. Hasil kadar abu tidak larut asam dalam ekstrak yang diperoleh masih dapat diterima karena masih berada pada rentang yang ditetapkan Farmakope Herbal Indonesia.

Penetapan kadar flavonoid total bertujuan untuk kontrol kualitas ekstrak etanol $70 \%$ daun A. scandens (L.) Moq. dengan senyawa golongan yang terdapat didalamnya adalah senyawa golongan flavonoid. Jika kadar flavonoid total dari ekstrak telah memenuhi persyaratan maka kadar flavonoid minimal yang terdapat pada ekstrak telah memenuhi standar. Kandungan flavonoid total minimal untuk ekstrak etanol $70 \%$ daun binahong menurut Farmakope Herbal Indonesia adalah tidak kurang dari $9,36 \% \mathrm{~b} / \mathrm{b}$ dihitung sebagai rutin. Pada metode ini digunakan panjang gelombang $425 \mathrm{~nm}$. Hasil penetapan kadar flavonoid total ekstrak etanol 70\% daun A. scandens (L.) Moq. telah memenuhi kadar flavonoid total ekstrak etanol $70 \%$ daun A. scandens (L.) Moq. yaitu 9,084 $\pm \%$ yang dihitung sebagai rutin.

\section{Uji Pendahuluan Toksisitas Akut Dermal Sediaan Salep Ekstrak Etanol 70\% Daun $A$. scandens (L.) Moq.}

Uji pendahuluan toksisitas akut dermal menjadi syarat sebelum dilakukannya uji utama toksisitas akut dermal. Uji pendahuluan toksisitas akut dermal penting dilakukan untuk mengetahui dosis dari sediaan salep ekstrak etanol 70\% daun A. scandens (L.) Moq. yang masih aman digunakan untuk kulit. Pengujian ini menggunakan sediaan salep ekstrak etanol $70 \%$ daun A. scandens (L.) Moq. yang ditempelkan pada kulit punggung tikus selama 24 jam. Penempelan bahan uji pada kulit punggung tikus bertujuan untuk memperpanjang kontak antara bahan uji dengan kulit tikus dan memudahkan bahan uji untuk terpenetrasi ke dalam kulit tikus. Penempelan bahan ujidilakukan pada punggung tikus, karena bagian punggung memudahkan untuk pengolesan bahan uji, bahan yang menempel tidak boleh mengalami gerakan, lepas ataupun kendor, yang akan membuat kontak dengan kulit cukup lama dan baik.Dilakukan penemepelan secara tertutup menggunakan kasa steril, perban, dan plester yang tidak mengiritasi, hal ini bertujuan untuk menjamin dan membantu absorbsi dari bahan 
uji serta menghindari dari pengaruh lingkungan (Sulakmono, 2001; Trihapsoro, 2003).

Delapan ekor tikus yang telah memenuhi kriteria uji dan diaklimatisasi sebelumnya dibagi menjadi 8 kelompok perlakuan. Bahan uji yaitu (K0) kontrol atau tanpa bahan uji, (K1) basis salep, (K2) ekstrak etanol $70 \%$ daun A. scandens (L.) Moq. dosis $1000 \mathrm{mg} / \mathrm{Kg} \mathrm{BB}$, (K3) ekstrak etanol 70\% daun A. scandens (L.) Moq. dosis $2000 \mathrm{mg} / \mathrm{Kg}$ $\mathrm{BB},(\mathrm{K} 4)$ ekstrak etanol $70 \%$ daun A. scandens (L.) Moq. dosis $5000 \mathrm{mg} / \mathrm{Kg} \mathrm{BB}$, (K5) salep ekstrak etanol $70 \%$ daun A. scandens (L.) Moq. dosis $1000 \mathrm{mg} / \mathrm{Kg} \mathrm{BB}$, (K6) salep ekstrak etanol $70 \%$ daun A. scandens (L.) Moq. dosis $2000 \mathrm{mg} / \mathrm{Kg} \mathrm{BB}$, dan (K7) salep ekstrak etanol $70 \%$ daun A. scandens (L.) Moq. dosis $5000 \mathrm{mg} / \mathrm{Kg}$ BB. Pengamatan dilakukan pada hari ke-1 setelah pelepasan bahan uji sampai hari ke-14 untuk mengamati ada atau tidaknya tikus yang mati. Hasil pengamatan dari delapan kelompok uji menunjukkan bahwa tidak adanya tikus yang mati selama 14 hari. Hal ini menunjukkan bahwa seluruh bahan uji aman untuk digunakan pada kulit dan tidak menimbulkan efek samping maupun reaksi toksisitas.

\section{SIMPULAN DAN SARAN}

\section{Simpulan}

Ekstrak etanol $70 \%$ daun A. scandens (L.) Moq. dalam penelitian ini telah memenuhi standar ekstrak etanol $70 \%$ daun binahong menurut Farmakope Herbal Indonesia yang dilihat dari parameter rendemen ekstrak, kadar air ekstrak, kadar abu total, kadar abu tidak larut asam, dan kadar flavonoid total. Sediaan salep ekstrak etanol $70 \%$ daun A. scandens (L.) Moq.yang diujikan pada hewan tikus tidak menyebabkan adanya kematian yang berarti sediaan salep ekstrak etanol $70 \%$ daun A. scandens (L.) Moq. aman digunakan untuk kulit.

\section{Saran}

Adapun saran yang dapat kami berikan pada penelitian selanjutnya diharapkan untuk melakukan uji toksisitas subkronis dermal.

\section{UCAPAN TERIMAKASIH}

Penulis menghaturkan terima kasih kepada Direktorat Pendidikan Tinggi Kementrian Pendidikan dan Kebudayaan Republik Indonesia dan Rektor Universitas Udayana melalui Program Studi Farmasi Fakultas Matematika dan Ilmu Pengetahuan Alam Universitas Udayana yang telah memfasilitasi dan mendanai penelitian ini. Mahasiswa/I Program Studi Farmasi Fakultas Matematika dan Ilmu Pengetahuan Alam Universitas Udayana yang masih aktif yang bersedia menjadi panelis dalam penelitian ini.

\section{DAFTAR PUSTAKA}

Ardinata, I. P. R., 2017, Profi Kromatografi Kandungan Fitokimia dan Aktivitas Fibrogenesis Ekstrak Etanol Daun Binahong (Anredera scandens (L.) Moq.) pada Penyembuhan Luka Eksisi, Skripsi, Jurusan Farmasi, Fakultas Matematika dan Ilmu Pengetahuan Alam, Universitas Udayana, Jimbaran.

Ariadi, K. A, 2016, Profil Kromatografi Kandungan Fitokimia dan Aktivitas Angiogenesis Ekstrak Etanol Daun Binahong (Anredera Scandens (L.) Moq.) pada Penyembuhan Luka Eksisi, Skripsi, Jurusan Farmasi, Fakultas Matematika Dan Ilmu Pengetahuan Alam, Universitas Udayana, Jimbaran.

BPOM, 2014, Peraturan Kepala BPOM Republik Indonesia Nomor 7 Tahun 2014 tentang Pedoman Uji Toksisitas Nonklinik Secara In Vivo, Badan Pengawas Obat dan Makanan Republik Indonesia, Jakarta.

Chandra, S. A., Stokes, A. H., Hailey, R., Merrill, C. L., Melich, D. H., Desmet, K., Furst, S. M., Peterson, R. A., Mellon-Kusibab, K., and Adler, R. R., 2015, Dermal Toxicity Studies: Factors Impacting Study Interpretation and Outcome. Toxicologic Pathology, 43 (4): 474-481.

Depkes RI, 1995, Farmakope Indonesia, Edisi IV, Departemen Kesehatan Republik Indonesia, Jakarta.

Feybriyanti, Y. W., 2011, Uji Aktivitas Antiinflamasi Ekstrak N-Heksan, Kloroform, dan Etanol Daun Binahong 
(Anredera scandens (L.) Moq.) pada Tikus yang Diinduksi Karagenan 1\%, Skripsi, Universitas Udayana, Denpasar.

Fitria, A., 2009, Uji Aktivitas Antibakteri Ekstrak Daun Anredera cordifolia (Tenore) Steen, Anredera scandens (L.) Moq., Basella rubra L. pada Bakteri Gram Positif dan Bakteri Gram Negatif, Skripsi, Universitas Udayana, Denpasar.

Hernani, Winarti, C., dan Marwati, T., 2009, Pengaruh Pemberian Ekstrak Daun Belimbing Wuluh Terhadap Penurunan Tekanan Darah pada Hewan Uji.Jurnal Penelitian Pascapanen Pertanian, 6 (1): 54-61.

Karismawan, P. D., 2013, Profil Kamdungan Kimia dan Uji Aktivitas Antiluka Bakar Ekstrak Etanol Daun Binahong (Anredera scandens (L.) Moq.) pada Tikus Jantan Galur Sprague Dawley, Skripsi, Universitas Udayana, Jimbaran.

Kementrian Kesehatan RI, 2011, Farmakope Herbal Indonesia, Edisi I, Departemen Kesehatan Republik Indonesia, Jakarta.

Kunle, O. F., Egharevba, H.O., and Ahmadu, P.O., Standardization of Herbal Medicines-A review,International Journal of Biodiversity and Conservation, 4 (3): 101-112.

Noakes, D. N. and Sanderson, D. M., 1969, A Method for Determining The Dermal Toxicity of Pesticides, Brit. J. Industr.Med, 26: 59-64.

Organization for Economic Cooperation and Development, 2002, OECD 404 Guidelines for Testing of Chemicals Acute Dermal Irritation/Corrotion.

Puri, N. P, 2017, Profil Kandungan Kimia dan Uji Aktivitas Fraksi Etil Asetat Ekstrak Etanol Daun Binahong (Anredera scandens (L.) Moq.) dalam Penyembuhan Luka Eksisi, Skripsi, Jurusan Farmasi, Fakultas Matematika dan Ilmu Pengetahuan Alam, Universitas Udayana, Jimbaran.

Remirez, D. C., 2006, Update in Pre-clinical Regulatory Requirements for
Phytomedicines in Latin America, Journal Complementary Integrative Medicine, 3 (1): 1-7.

Samirana, P. O., Leliqia, N. P. E., and Ariantari, N. P., 2014, TLCDensitometer Profile and Antiulcer Activity Assay of Ethanol Extract of Binahng Leaves (Anredera scandens (L.) Moq.) in Sprague Dawley Strain Male Rats, Proceeding, The International Conference Pharmaceutical Care.

Samirana, P. O., Swastini, D. A., Subratha, I. D. G. P. Y., dan Ariadi, K. A., 2016, Uji Aktivitas Penyembuhan Luka Ekstrak Etanol Daun Binahong (Anredera scandens (L.) Moq.) pada Tikus Jantan Galur Wistar, Jurnal Farmasi Udayana, 5 (2): 19-23.

Subratha, I. D. G. P. Y., 2016, Profil Kromatografi Kandungan Fito-kimia dan Aktivitas Epitelisasi Ekstrak Etanol Daun Binahong (Anredera Scandens (L.) Moq.) pada Penyembuhan Luka Eksisi, Skripsi, Jurusan Farmasi, Fakultas Matematika dan Ilmu Pengetahuan Alam, Universitas Udayana, Jimbaran.

Sulakmono, 2001, Keuntungan dan Kerugian Patch Test (Uji Tempel) dalam Upaya Menegakkan Diagnosa Penyakit Kulit Akibat Kerja (Occupational Dermatosis), Universitas Airlangga, Surabaya.

Trihapsoro, I., 2003, Dermatitis Kontak Alergi pada Pasien Rawat Jalan di RSUP Haji Adam Malik Medan, Universitas Sumatra Utara, Medan.

Wardhani, L. K., dan Sulistyani, N., 2012, Uji Aktivitas Antibakteri Ekstrak Etil

Asetat Daun Binahong (Anredera scandens (L.) Moq.) terhadap Shigella fexneri Beserta Profil Kromatografi Lapis Tipis, Jurnal Ilmiah Kefarmasian, 2 (1): 1-1.

WHO, 1998, Quality Control Method for Herbal Materials, World Health Organization, Malta. 